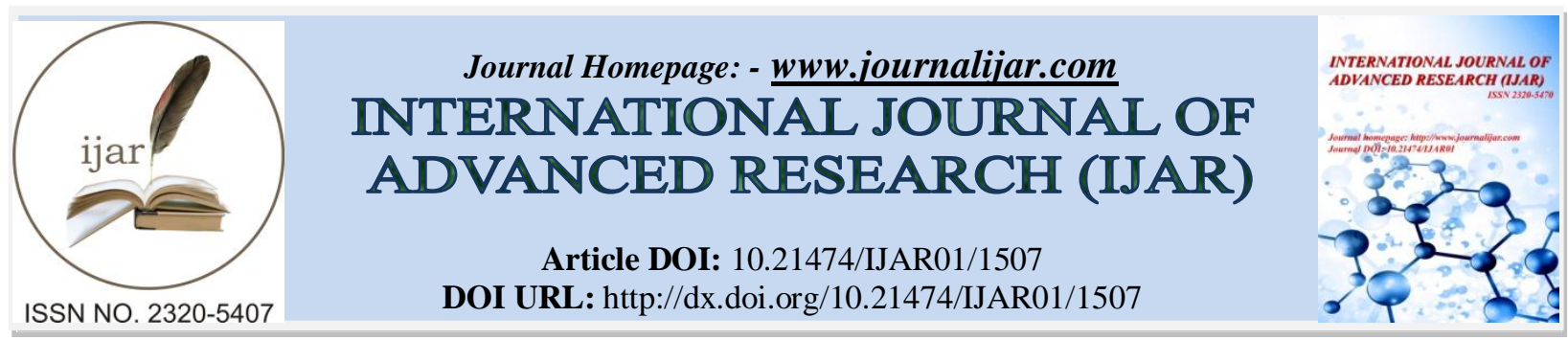

RESEARCH ARTICLE

\title{
INSECT'S POPULATION PREFERABLE BY BIRDS IN THE DIFFERENT ECOSYSTEMS OF TANDOJAM SINDH, PAKISTAN
}

\author{
Afghan Ambreen ${ }^{1}$, Riffat Sultana ${ }^{1}$ Ghulam Sarwar Gachal ${ }^{1}$, Muhammad Saeed Wagan ${ }^{1}$ and Fakhra \\ Soomro ${ }^{2}$. \\ 1. Department of Zoology, University of Sindh, Jamshoro, Pakistan. \\ 2. Department of Zoology, Shah Abdul Latif University, Khairpur, Pakistan.
}

\section{Manuscript Info \\ Manuscript History \\ Received: 22 July 2016 \\ Final Accepted: 29 August 2016 \\ Published: September 2016}

Key words:-

Maximum, mosquito, thrips, bugs, grasshoppers, birds

\begin{abstract}
During the present study maximum population of insects was observed in the fields such as Mosquitoes i-e 9.89\% followed by $9.02 \%$ of Ants larvae, $8.55 \%$ of Scale insects, $8.35 \%$ of Fruits flies, $8.04 \%$ of Thrips and $8.0 \%$ of Bugs respectively. Whereas, lowest population of American bollworm and Thin larvae i.e 2.29\% and $1.67 \%$ was calculated from five different ecosystems of Tandojam. Grasshoppers and locusts population was noted $6.92 \%$ in all survey fields. Overall it was observed that insect's population was maximum i-e 566 from Horticulture followed by 528 and 511 from Malir farm and S.A.U Tandojam while lowest No. of insects i-e 487 and 480 were reported from H.M.S Baloch and L.A farm.
\end{abstract}

Copy Right, IJAR, 2016, All rights reserved.

\section{Introduction:-}

Insects are polyphagous plants pest belongs to different orders they are widely distributed from sea level to snowy mountains with significant economic importance due to their destructive role to almost all type of green vegetations. Different members of class insecta probably qualify as best food source for birds. They are the tastiest, nourishing and generally desirable food items for many species of birds, reptiles and mammals. Locust swarms are often accompanied by flocks of birds which gorge themselves as a unit. Insects are easily captured by birds due to variety of reasons such as soft bodied, smaller in size and easier to handle. Most of the birds will comb everything creeping on ground, herbs, shrubs and trees. The proportion of insects in the diet of these birds varies with the seasons. Considerable taxonomic work has been carried out on the insects of plain, cultivated and semi-mountainous area by (Tandon and Shishodia, 1969 and 1989; Tandon, 1975-1976; Riffat and Wagan 2008 and 2010 ; Mukhtar et al., 2010; Nayeem et al., 2012). Birds can play significant role to control insect's pest population below the threshold level. But very little attention has been paid to use them as a bio-control agent. Introduction of birds as predator to control the insect pest population is new trend in Pakistan. Birds not only contributing to control pest population but they are also playing significant role to maintain the balance in the food chain of ecosystem. Therefore, present initiative has been made to enlist different orders of insects preferable by birds.

\section{Material and methods:-}

\section{Insect's sampling:-}

Culture of insects (both nymphs and adults) captured from different agriculture ecosystem i-e wheat, sunflower, sugarcane, fruits and vegetables forms which mostly surrounded by wild plantation of various grasses. All samples were captured through insect net $(9.5 \mathrm{~cm}$ in diameter and $51.5 \mathrm{~cm}$ in length) while some of them were picked by 
hand or large forceps. Sampling was done during 2015 during month of February to late December from Tandojam. After collection insects were shifted into plastic bags/ cages/ jars and brought to laboratory.

\section{Recognition of insect:-}

Identification of species was done under stereoscope microscope, through literature and direct communication and guide line of supervisor.

Statistical examination:-

Experimental data was subject to one way analysis of variance (ANOVA) version (SPSS 16.0) applicable for window -8 .

\section{Results and Discussion:-}

During the present study maximum population of insects were observed in different ecosystems i.e Mosquitoes 9.89 $\%$ followed by $9.02 \%$ Ants Larvae, $8.55 \%$ of Scale insects, $8.35 \%$ of Fruits flies, $8.04 \%$ of Thrips and $8.0 \%$ of Bugs respectively. Whereas, lowest population of American bollworm and Thin larvae i.e $2.29 \%$ and $1.67 \%$ was calculated from five different ecosystems of Tandojam. Grasshoppers and locusts population was noted $6.92 \%$ in all survey fields. Over all it was observed that insects population was maximum i-e 566 from Horticulture followed by 528 and 511 from Malir farm and S.A.U Tandojam while lowest No. of insects i-e 487 and 480 were reported from H.M.S Baloch and L.A farm (Table-1).

Grasshopper's population was increased with rains, but they were not migratory and caused less damage. From 1986-90 applications of insecticides for locust control were made to almost 14 million ha in northern Africa (Everts, 1990). About one -half of the area treated was in North Africa from Morocco to Egypt. The rest was in the Sahel from Mauritania and Senegal to Ethiopia. While most applications for locust control were made in relatively small areas $(1-12 \mathrm{~km} 2)$, to larger areas $\left(100 \mathrm{~km}^{2}\right)$ were treated for control of grasshopper populations both with organophosphate and carbonate. Insecticides persisted for only a few days in the dry environments (Everts, 1990). Migrating locusts represent one of the largest biomass of insects ever to congregate on earth. In Somalia, one plague area was estimated to contain 1.6 billion locusts weighing 50, 000 tons (Rowley, 1993).

Such concentration attracts large numbers of resident and migratory birds that often travel with Swarms of locusts. (Smith and Popov, 1953) observed thousands of eagles and falcons feeding for days on swarm containing tens of millions of locusts. Many raptors feed on locusts and the African Cuckoo Falcon (Aviceda cuculoides), Montagu's Harrier (circus pygargus), Red-footed Falcon (Falco vespertinus), Amur Falcon (Falco amurensis) and Lesser Kestrel (Falco naumanni) are considered locust and grasshopper specialists (Steedam, 1988; Pickford et al., 1989). Controlled studies of the environmental effects of locust control are not possible during operational applications of insecticides to moving swarms of locusts. However, several experimental applications of insecticides to large study plots have been evaluated. (Risser et al., 1981) reported that insects' population significantly decrease in forest system naturally by insectivores birds, it was necessary to demonstrate similar results in grasslands. Insectivorous birds are relatively scare in green land compared to forest habitats and it has been recommend that avian predation is likely to be significant to control insect pest population in grassland.

Population densities of insects in various ecosystems of Tandojam were found maximum in order Hymenoptera; ants and their thin larvae, leaf cutter ants and their larvae Diptera; mosquitoes, fruit flies, hoverflies, black flies Thysanoptera; thrips Hemiptera; bugs, aphid, scale insects Isoptera Subterranean termites Lepidoptera; army worm, american bollworm, citrus butterfly Coleoptera; beetles Orthoptera; locusts and Grasshoppers Dictoptera; praying mentis. These species of insects are more commonly eaten by birds; this is the first attempt of such comparative examination of co-existing population of birds and insects in this permissive (Table-3). 
Table 1:- Insect population present in different ecosystems of Tandojam during the year 2015-2016.

\begin{tabular}{|l|l|l|l|l|l|l|l|}
\hline S.No. & \multicolumn{1}{|c|}{$\begin{array}{c}\text { Insects } \\
\text { Haji MS } \\
\text { Farm }\end{array}$} & $\begin{array}{c}\text { SAU } \\
\text { Horticulture }\end{array}$ & $\begin{array}{c}\text { S.A.U } \\
\text { Farm }\end{array}$ & $\begin{array}{c}\text { L.A } \\
\text { Farm }\end{array}$ & $\begin{array}{c}\text { Malir } \\
\text { Farm }\end{array}$ & $\begin{array}{c}\text { Percentage } \\
(\%)\end{array}$ \\
\hline 1. & Ants larvae & 29 & 63 & 57 & 48 & 35 & $9.02 \%$ \\
\hline 2. & Leaf Wasp & 15 & 39 & 17 & 14 & 19 & $4.04 \%$ \\
\hline 3. & Thin larvae & 05 & 18 & 15 & 05 & 00 & $1.67 \%$ \\
\hline 4. & Mosquitoes & 82 & 42 & 51 & 39 & 40 & $\mathbf{9 . 8 9 \%}$ \\
\hline 5. & Fruit flies & 39 & 56 & 41 & 46 & 33 & $8.35 \%$ \\
\hline 6. & Black flies & 00 & 07 & 05 & 13 & 00 & $0.97 \%$ \\
\hline 7. & Thrips & 52 & 63 & 37 & 26 & 29 & $8.04 \%$ \\
\hline 8. & Scale insect & 29 & 38 & 42 & 50 & 61 & $8.55 \%$ \\
\hline 9. & Bugs & 63 & 52 & 40 & 22 & 29 & $8.00 \%$ \\
\hline 10. & Aphids & 21 & 41 & 33 & 16 & 27 & $5.36 \%$ \\
\hline 11. & $\begin{array}{l}\text { Subterranean } \\
\text { termites }\end{array}$ & 23 & 20 & 39 & 52 & 32 & $6.45 \%$ \\
\hline 12. & $\begin{array}{l}\text { American } \\
\text { Bollworm }\end{array}$ & 05 & 02 & 13 & 20 & 19 & $2.29 \%$ \\
\hline 13. & Beetle & 42 & 29 & 30 & 31 & 32 & $6.37 \%$ \\
\hline 14. & Army worm & 42 & 32 & 40 & 29 & 40 & $7.11 \%$ \\
\hline 15. & Citrus butterfly & 21 & 24 & 22 & 33 & 07 & $4.16 \%$ \\
\hline 16. & $\begin{array}{l}\text { Locust } \\
\text { Grasshopper }\end{array}$ & 19 & 20 & 29 & 36 & 74 & $6.92 \%$ \\
\hline & Total & 487 & 566 & 511 & 480 & 528 & $2572 \%$ \\
\hline
\end{tabular}

Table 2:- Showing the insect population along with their target crops.

\begin{tabular}{|l|l|l|l|}
\hline \multicolumn{1}{|c|}{ S.No. } & \multicolumn{1}{|c|}{ Common Name } & \multicolumn{1}{|c|}{ Scientific Name } & \multicolumn{1}{c|}{ Main Target Crop } \\
\hline 1. & Large Grasshopper & Hieroglyphus perpolita & Wheat \\
\hline 2. & Rice Grasshopper & H. nigrorepletus & Rice \\
\hline 3. & Small Grasshopper & H. orzivorus & Sun flower \\
\hline 4. & Small Grasshopper & Oxya hyl ahyla & Cabbage \\
\hline 5. & Grasshopper & O. velox & Rice,Tomato \\
\hline 6. & Locust & Locusta migratoria & Chilli \\
\hline 7. & Locust & Schistocerca gregaria & Wheat \\
\hline 8. & Mustard Aphid & Lipaphise rysimidavis & Lady finger \\
\hline 9. & Painted Bug & Badga cruciferum kirk & Sun flower \\
\hline 10. & Mustard Sawfly & Athalico proximaklug & Green Beans \\
\hline
\end{tabular}

Table 3:- Showing the orders of different insects preferable by birds.

\begin{tabular}{|l|l|l|}
\hline \multicolumn{1}{|c|}{ S.No. } & \multicolumn{1}{|c|}{ Order } & \multicolumn{1}{c|}{ Insects } \\
\hline 1. & Hymenoptera & Ant thin Larvae, Leaf cutter, Ants, Wasps and their larvae \\
\hline 2. & Diptera & Mosquitoes, Fruit flies, Haver flies, Black flies \\
\hline 3. & Thysanoptera & Thrips \\
\hline 4. & Hemiptera & Bugs, Aphids, Scale insects \\
\hline 5. & Isoptera & Subterranean termites \\
\hline 6. & Lepidoptera & Army worm, American boll worm, Citrus butterfly \\
\hline 7. & Coleoptera & Beetles \\
\hline 8. & Orthoptera & Locust, Grasshoppers \\
\hline 9. & Dictoptera & Praying mantis \\
\hline
\end{tabular}




\section{Reference:-}

1. Everts, J.W. [ed.]. 1990. Environmental effects of chemical locust and grasshopper control: a pilot study. Project report. Project ECLO/SEN/003/NET. FAO/ UN.Rome, Itlay.

2. Mukhtar, G.S., M. Nawaz, N. Yasmin, and A. Kakar. 2010. Biodiversity and occureence of grasshoppers (Acrididae: Ortoptera) of Quetta division Baluchistan. Pakistan J. Zool.42 (1) :87-91.

3. Nayeem M.R. and M.K. Usmani M.K. 2012. Taxonomy and field Observation of Grasshoppers and Locust Fauna (Ortoptera:Acridoidea) Munis Entom. Zool. 7(1):391-471

4. Pickford, S., J. Cunningham, R. Lynch, J. Radice, and G. White, 1989. Government Economics Statistics: A security report, London. HMSO.

5. Rowley, J. 1993. Grasshoppers and locusts - the plague of the Sahel. The Panos Institute, London, U.

6. Risser, P.G., E.C. Birney, H.D. Blocker, S.W. May, W.J. Parton, and J.A. Wiens, 1981. The true prairie ecosystem. Hutchinson. Ross. Stroudsburg, P.

7. Riffat S. and M.S Wagan, 2008. Notes on the taxonomy, distribution and ecology of Hieroglyphus nigrorepletus I . bolivar, 1912 (Hemiacridinae: Acrididae: Orthoptera) a major paddy pest in Pakistan Pakistan J. Zool. 40 (1): 19-23.

8. Riffat, S., M.S. Wagan, 2010. Systematic status and ecology of Hieroglyphus perpolita (Uvarov, 1932) ( Acrididae: Orthoptera) of Pakistan. Pakistan J. Zool., 42: 67-72.

9. Riffat, S. and M.S. Wagan, 2010. The effect of various Host plants on nymphal development and egg production in Hieroglyphus perpolita ( Uvarov) ( Hemiacridinae : Acrididae: Orthoptera). Trop. Zool. 23:1-7.

10. Smith, G.J. 1987. Pesticide use and toxicity in relation to wildlife:organophosphorus and carbamate compounds. Fish wildl.Serv.Resour. Publ.170.USDI, Washington, DC U.S.A.

11. Smith, J.D. and G.B. Popov, 1953. On birds attacking desert locust swarms in Eritrea. Entomologist. 86:3-7.

12. Steedman, A. [ED.]. 1988. Locust handbook. Overseas development natural resources institute. London. UK.

13. Tandon, S. K. And M.S. Shishodia, 1969. On a collection of Acridoidea (Orthoptera) from the Nagarjuna Sagar Dam Area. Oriental insects. 3 (3): 265-267.

14. Tandon, S. K. 1975. On the genus CondracrisUvarov (Insecta: Orthoptera: Acridoidea: Acrididae: Crytacanthacridinae) in India. Dr. B.S. Chauhan Comm., 395-402.

15. Tandon, S. K. 1976. A Check list of the Acridoidea (Orthoptera) of India Part 1Acrididae. Rec. Zool. Surv. India. Occ. 3: 1-46.

16. Tandon, S. K. and M.S. Shishodia, 1989. Fauna of Orissa. State fauna series 1 (P-2) : 93-145. 